\title{
Phylogenetic tree analysis study of bovine papillomaviruses type 1 based on L1 gene in Al-Qadisiyah governorate, Iraq
}

\author{
K.A. Mansour ${ }^{1}$, H.H. Naser ${ }^{2}$ and M.H. Hussain ${ }^{3}$ \\ College of Veterinary Medicine, University of Al-Qadisiyah, Al-Qadisiyah - Iraq \\ ${ }^{1}$ khalefa.mansour@qu.edu.iq, ${ }^{2}$ hassan_iq84@yahoo.com, ${ }^{3}$ muthannahussain@gmail.com
}

(Received May 22, 2018; Accepted June 22, 2018)

\begin{abstract}
Bovine fibropapilloma and papilloma occur in different parts of the skin of animals. Bovine Papillomavirus (BPV) is an oncogenic virus making benign tumor lesion of together mucosal and cutaneous tissue in cattle. In order to confirm the clinical diagnosis; the study planned to make the molecular detection of BPV (DNA) using Polymerase Chain Reaction (PCR) from skin lesions and the phylogenetic analysis. Thirty-eight samples of skin lesions were collected from cattle clinically suspected to be infected with bovine papilloma virus from herds in Al-Qadisiyah Governorate in 2016, the primary clinical diagnosis depended on the morphological appearance and features of the lesion. Deoxyribonucleic Acid (DNA) was extracted from skin lesions; the DNA was examined by PCR technique using specific primer to BPV-1 /L gene-1. Twenty-two samples out of 38 $(57,9 \%)$, which were collected from different regions in Al-Qadisiyah Governorate, were positive. The sequences of four positive samples of DNA product amplification of (BPV) type-1, L1 gene confirmed the PCR results. These samples had the DNA presented in four accession numbers KY662042-1, KY662043-1, KY662040-1 and KY662041-1. This study proofed that cutaneous bovine papillomatosis related with BPV-1 infection in the cattle herds has affinity to solid skin rather than other epithelial and mucosal tissue.
\end{abstract}

Keywords: Papilloma, Cattle, PCR, DNA Sequence Available online at http://www.vetmedmosul.com

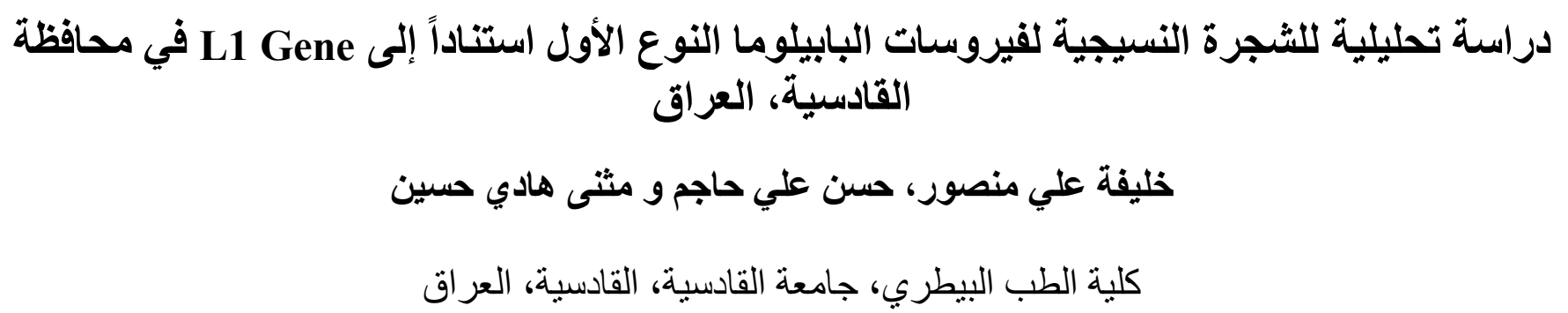

يحلاثة الورم الليفي الحليمي في أجزاء مختلفة من الجلد من الحيو انات، إن فيروس الثألول هو فيروس مسرطن يصنع آفة ورمية حميدة

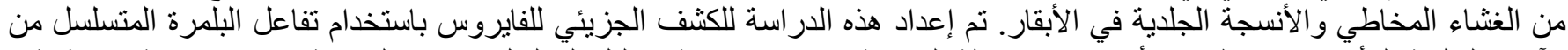

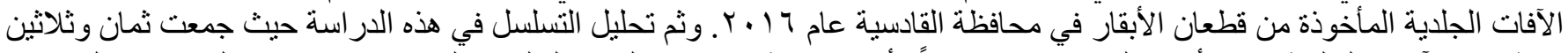

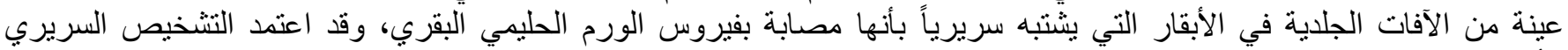

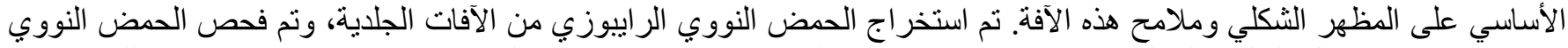

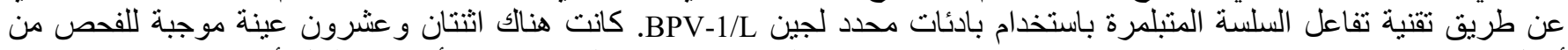

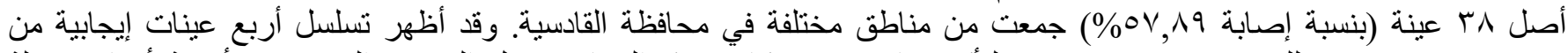

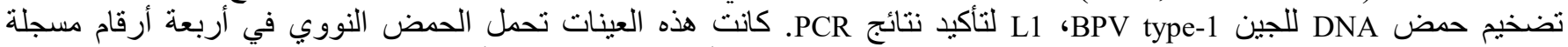
بالعذوى بالعدوى BPV-1 في قطعان المانشية له صلة بالجلد فقط بدلاً من الأنسجة الظهارية والأنسجة المخاطية الأخرى. 


\section{Introduction}

There are several skin diseases of cattle, most common among such skin infections are dermatophilosis, lumpy skin disease and cutaneous papillomatosis known as warts (1). Bovine papillomaviruses (BPVs) are a heterogeneous group of viruses responsible for tumors of the skin, genital, paragenital area, eye, upper gastrointestinal tract and urinary bladder (2). BPVs, like all other papillomaviruses (PVs), are usually strictly species specific, However, cases of cross-species infection are known to occur. BPV type 1 (BPV-1) and BPV-2, belonging to the genus Delta papilloma virus (3), are responsible for infections in equines resulting in sarcoids $(4,5)$, as well as in bison and water buffaloes leading to warts $(6,7)$. Bovine papillomavirus (BPV) is an etiological agent associated with several forms of cutaneous and mucosal papilloma (8). Six different types of BPVs have been distinguished on the basis of DNA sequence relatedness, each BPV is associated with type-specific lesions (9). BPV-1 and BPV-2 are classified in the genus Delta papilloma virus and infect the epithelium and dermis, giving rise to fibropapilloma; while BPV-3, BPV-4 and BPV-6 are classified in the genus Xipapilloma virus and are strictly epitheliotropic, inducing true epithelial papillomas, and BPV-5 is classified in the genus Epsilon papillomavirus and infects the epithelium and dermis, inducing both fibropapillomas and true epithelial papilloma of the skin (10). The important types BPV1 and BPV2 are unusual in their capability to infect together the epithelial cells tissue and the fibroblasts of the basic dermis and epidermis, producing fibropapilloma of the different site of the body teats, skin and udders, in addition to urinary bladder tumor in the cow (11). Although the detection of bovine papilloma virus type-1, clinical and epidemiological studies have been providing a new vision for the therapeutic and prevention measures of papillomatosis infections (12). There are several molecular studies about the occurrence of BPV in Iraq; the objective of this study was to identify the BPV types in cattle population that associated with papillomatosis in several regions.

\section{Materials and methods}

\section{Sample collection}

Thirty eight skin samples (warts) were collected from animals that were suffering from disruption of skin lesion on different areas from the body included shoulder, neck, around eyes, chin, perianal region, and clinically suspected to be infected with cutaneous bovine papillomatosis. The samples were collected by cutting the whole mass by forceps and surgical blade; then they were put in container and sent to the laboratory in cool box as soon as the molecular analysis were done.

\section{Viral DNA extraction}

Viral genomic DNA was extracted from frozen skin lesions (warts) samples using USA, Geneaid, DNA Mini Kit. The genomic viral DNA extraction was done based to company directions using tissue extraction procedure technique with proteinase $\mathrm{K}$. The extracted DNA was tested using Nanodrop spectrophotometer that check DNA concentration and DNA purity through construing the absorbance at $160 / 210 \mathrm{~nm}$.

\section{PCR amplification}

PCR was done for recognition and genotyping of bovine papillomavirus; it was performed using definite primer for L-major capsid protein gene. The primers were designed according to (13).

Forward 5-(CGGGGCCAAAACTGTTCCTA)-3-

Reverse $3^{-}$-(AATTCAAGAGGAGGGCAGGC)-5

The master mix tube of PCR was set using kit of PCR PreMix AccuPower ${ }^{\circledR}$, Korea Bioneer. The premix tube of PCR which contains pellet freeze-dried of Taq polymerase $1 \mathrm{U}, 10 \mathrm{mM}$ pH 9.0 of Tris- $\mathrm{HCl}$ dNTPs $250 \mu \mathrm{M}, \mathrm{MgCl}_{2} 1.5$ $\mathrm{mM} \mathrm{KCl} 30 \mathrm{mM}$, tracking dye and stabilizer.

The master mix of PCR reaction was set allowing to kit directions in $50 \mu \mathrm{l}$ total volume by add $3 \mu \mathrm{l}$ of 10 pmole of reverse primer, $3 \mu \mathrm{l}$ of 10 pmole of forward primer $10 \mu \mathrm{l}$ of purified genomic DNA and, then complete the premix tube of PCR by deionized distilled water PCR water into $30 \mu \mathrm{l}$ and fleetingly mixed by vortex centrifuge.

The reaction of PCR was done by setting up a thermocycler following conditions; the temperature of initial denaturation $95{ }^{\circ} \mathrm{C}$ for $5 \mathrm{~min}$; the cycles 30 of denaturation in $95{ }^{\circ} \mathrm{C}$ for $30 \mathrm{~s}$, annealing $58{ }^{\circ} \mathrm{C}$ for $30 \mathrm{~s}$, and extension $72{ }^{\circ} \mathrm{C}$ for $30 \mathrm{~s}$ and final extension at $72{ }^{\circ} \mathrm{C}$ for $5 \mathrm{~min}$. The PCR products $399 \mathrm{bp}$ were tested by electrophoresis in an agarose gel 1.5\% that stained with ethidium bromide, and pictured beneath UV illuminator.

\section{DNA sequencer}

The partial DNA sequencing for phylogenetic tree analysis of bovine papilloma was done based on capsid protein $\mathrm{L} 1$ gene. The PCR product of positive samples were sent to Korea (Bioneer Company) for complete DNA sequencing depend on $\mathrm{gpB}$ forward primer by sequencing system (AB-DNA).

The partial Sequence of four positive samples for bovine papilloma virus was submitted at the GenBank database under the accession numbers KY662040.1, KY662041.1, KY662042.1 and KY6620431. The analysis of Phylogenetic tree was performed according to (UPGMA tree) with Arithmetic Mean in (MEGA 6.0 version). 


\section{Result}

\section{Clinically}

The BPV-1 has affinity for thick skin, therefore the lesion appears commonly with solids shaped, and the lesion looks most commonly on the skin rather than other mucosa or organs.

\section{PCR Amplification}

The results of endpoint PCR for detection of bovine papilloma virus in ethidium bromide-stained agarose gel using specific primers for detection L1 gene at $399 \mathrm{bp}$ had twenty-two positive tissue skin samples out of thirty-eight which were collected from different regions in AlQadisiyah Governorate as presented in figure 1.

The PCR assay came out to confirm clinical diagnosis of the disease, the analysis of PCR results showed that the bovine papillomatosis found in Al-Qadisiyah were induced by bovine papilloma virus type 1 (BPV-1).

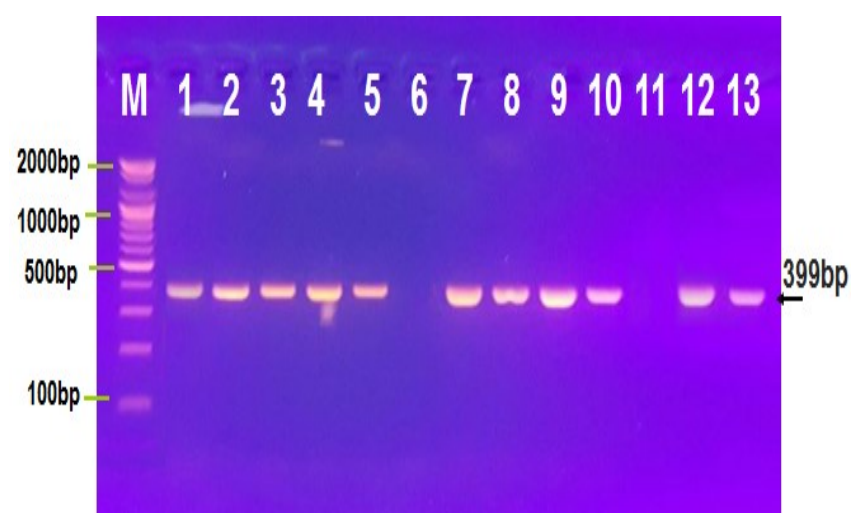

Figure 1: The results of endpoint of PCR products of BPV type-1, L1 gene in cattle warts. Lane 1, 2, 3, 4, 5, 7, 8, 9, 10,12 and 13 were positive results. Lane 6 and 11 were negative results.

\section{Sequencing of local Iraqi isolate of bovine papillomavirus}

The sequences of DNA amplification product of BPV type-1, L1 gene has come out to confirm PCR result mentioned above, the bovine papillomatosis caused by bovine papillomavirus type -1 in a crossbreed of the cattle population in a different area of Al-Qadisiyah Governorate. The sequence of four local Iraqi isolates were submitted by gene bank under number KY662042-1, KY662043-1, KY662040-1 and KY662041-1.

\section{Phylogenetic tree analysis}

The phylogenetic tree was directed using the partial genome sequence of local Iraqi isolates between them. The tree showed that IQ-isolate KY662042-1, KY662043-1 and
KY662040-1 were arranged in the same node in the tree, but the KY662041-1 was located in a close branch of tree as presented in figure 2 . The result of alignment showed a high identity $100 \%$ in sequence of Iraqi isolates KY662042-1,KY662043-1 and KY662040-1 where as small variety with KY662041-1 99\% as showed in figure 3 .

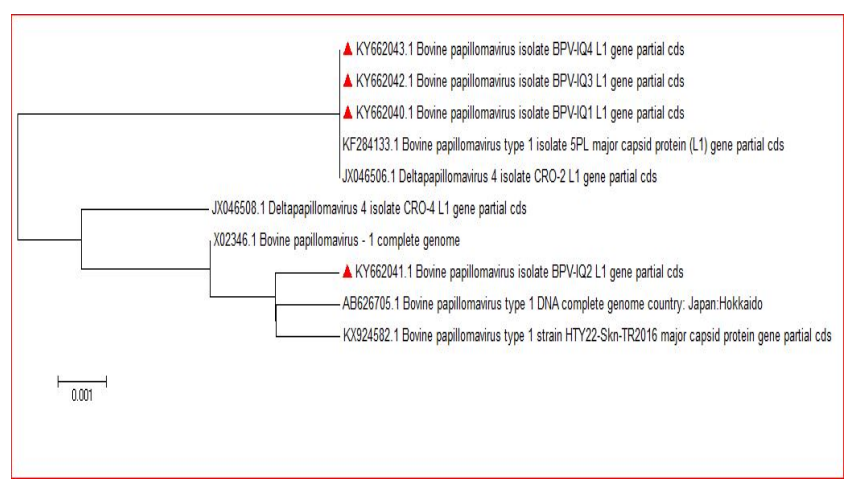

Figure 2: Phylogenetic tree of bovine papilloma virus type1 of Iraqi isolates (partial genome) with other world reference using a neighbour joining method (Mega: 6 program).

According to sequences alignment and present identity, the Iraqi isolate KY 622041.1 indicate high similarity 100\% to the sequences obtained from the Croatian isolate JX046508.1, Turkey isolate KX924582.1, and Japan isolate AB62605.1 as offered in figure 3. Analysis of the tree revealed that these isolates were clustered together in the identical node and in the same branches with the Iraqi isolate KY662041.1. The results of the tree analysis showed that the other three Iraqi isolate KY662042-1, KY662043-1 and KY662040-1 are clustered together with Poland isolate KF284133.1 and Croatia isolate JX046506.1.

\section{Discussion}

Papillomatosis in cattle is associated with BPV type 1 and type $2(14,15)$. The present study showed molecular detection of BPV type-1 in thirty-eight cutaneous samples of cattle papillomatosis in Al-Qadisiyah Governorates using specific primers, these results are similar to those presented by (14-17). The specific primers were used to identify genotype and characterize BPV type 1, and this finding was confirmed by partial sequencing and studying the phylogenetic tree analysis, so it could be the most suitable assay for characterizing BPV as discovered by $(12,18)$.

There are several studies about BPV in many Iraqi Governorates $(13,19,20)$ which have been led to determine the incidence of bovine papillomatosis infection in cattle, they had prevailed the types of the BPV, their geographic area distributions, methods of treatment. This study with a 
few previous studies focused on the confirmation of the PCR-based molecular diagnosis of bovine papilloma virus type -1 , by sequencing and phylogenetic tree analysis. So, in this study it was confirmed that the skin cattle wart (papillomatosis) occurred in an outbreak in Al-Qadisiyah
Governorate in 2016 caused by bovine papilloma virus from which four samples were sequenced, confirming the occurrence of BPV-1 under the genus Deltapapillomavirus. These results agreed with (21) in Turkey in 2016, it may be related to the geographical distribution and climate.

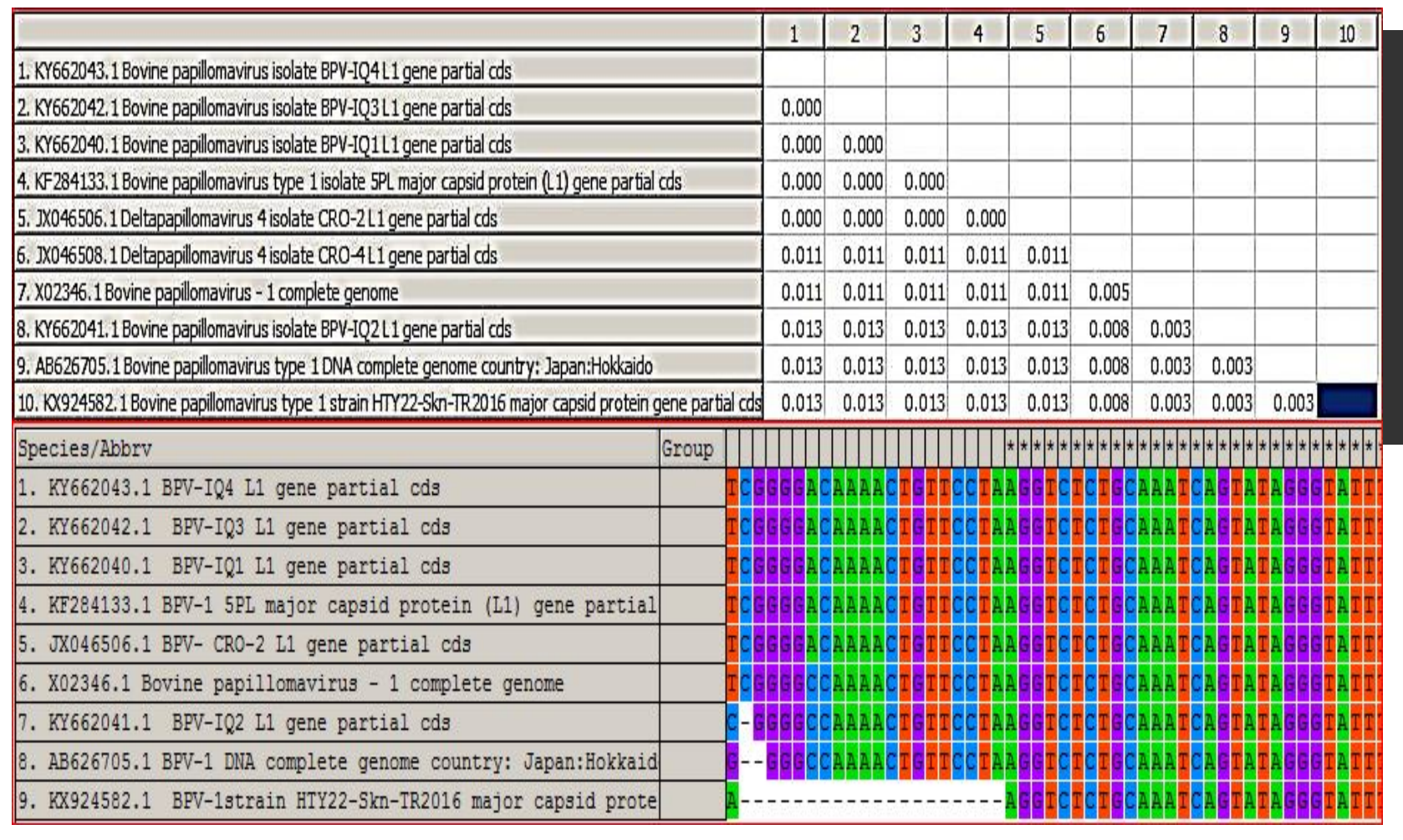

Figure 3: Multiple alignment sequence of BPV Type -1 of Iraqi isolate and some other selected references in the world.

According to the phylogenetic tree analysis; IQ-isolate KY662042-1, KY662043-1 and KY662040-1 were arranged in the same node of the tree and clustered together closely with complete similarity in nucleotide sequence, also there was some sequential differences and similarities between the other collected samples such as those of the Polish isolate KF284133.1 and the Croatian isolate JX046506.1. However, when the study has identified only one genotype BPV-1, these results suggested that the animals in the area of the study are more susceptible to BPV-1, or it seems to be that Iraq is endemic with this type only. This finding is similar with other studies in Iraq (13).

When three types were banded together (similar in expressions of nucleotide sequences) in the same subcluster, they have been closely related to each other and similar in terms of nucleotide sequences. It's also found some sequential differences KY662041-1 among the other collected samples. The isolate KY662041-1 was located in near branch of the tree. The comparison of alignment showed high identity $100 \%$ among the Iraqi isolates
KY662042-1, KY662043-1 and KY662040-1 where as small variety with isolates KY662041-1 99\%. This finding agreed with other studies $(13,15)$

In conclusion, the BPV-1 has affinity for thick skin, therefore the lesion appears commonly with solids shaped, and the lesion looks most commonly on the skin rather than other mucosa or organs. Also, the study showed that skin BPV-1 infection was present in Al-Qadisiyah Governorate, Iraq conducting more molecular studies is required to diagnose if there are other types of the disease in the same area of study and other geographical areas of Iraq.

\section{References}

1. Radostits OM, Gay CC, Hinchcliff KW, Constable PD, Jacobs DE, Ikede BO, Bildfell RJ. Veterinary medicine: A textbook of the diseases of cattle, sheep, pigs, goats and horses. $9^{\text {th }}$ ed. London: WB Saunders; 2010;667 p.

2. IARC. Monographs on the evaluation of carcinogenic risks to humans. Lyon: IARC Press; 2007. 54 p.

3. DeVilliers EM, Fauquet C, Broker TR, Bernard HU, zur Hausen H. Classification of papillomaviruses. Virology. 2004;324:17-27. 
4. Chambers G, Ellsmore VA, O'Brien PM, Reid SW, Love S, Campo MS, Nasir, L. Association of bovine papillomavirus with the equine sarcoid. J Gen Virol. 2003,84:1055-1062.

5. Trenfield K, Spradbrow PB, Vanselow B. Sequences of papillomavirus DNA in equine sarcoids. Equine Vet J.1985;17:449452.

6. Litera KI, Tomita Y, Ogawa T, Shirasawa H, Smıd B, Novotny L, Adamec M. Papillomatosis in a European bison. J Wildl Dis. 2006,42:149-153.

7. Silvestre O, Borzacchiello G, Nava D, Iovane G, Russo V, Vecchio D, D'Ausilio F, Gault E A, Campo MS, Paciello O. Bovine papillomavirus type 1 DNA and E5 oncoprotein expression in water buffalo fibropapillomas. Vet Pathol. 2009,46:636-641.

8. Campo MS. Animal models of papillomavirus pathogenesis. Virus Res. 2002,89:249-261.

9. Jarrett WFH, Campo MS, O’Neil BW, Laird HM, Coggins LW. A novel bovine papillomavirus (BPV-6) causing true epithelial papilloma of the mammary gland skin: a member of a proposed new BPV subgroup. Virology. 1984;136:255-264.

10. Bloch N, Sutton RH, Spradbrow PB. Bovine cutaneous papillomas associated with bovine papillomavirus type 5. Arch Virol. 1994;138:373-377.

11. Nasir L, Campo MS. Bovine papillomaviruses: their role in the etiology of cutaneous tumors of bovids and equids. Vet Dermatol. 2008,19(5):243-254.

12. Grindatto A, Ferraro G, Varello K, Crescio MI, Miceli I, Bozzetta E, Goria M, Nappi R. Molecular and histological characterization of bovine papillomavirus in North West Italy. Vet Microbiol. 2015;180:113-117.

13. Khalefa AM. Clinical, histopathological and molecular detection of cutaneous papillomatosis associated with bovine papillomavirus types 1and 2 in cattle from Al-Qadissiyia Governorate. Kufa J Vet Med Sci. 2016;7(1):182-191.

14. Santos EUD, Silva MAR, Pontes NE, Countinho LCA, Paiva SSL, Castro RS, Freitas AC. Detection of different bovine papillomavirus types and co-infection in bloodstream of cattle. Transbound Emerg Dis. 2016;63:103-108.

15. Hamad M, Al-Shammari AM, Odisho SM, Yaseen NY. Molecular epidemiology of bovine papillomatosis and identification of three genotypes in central Iraq. Inter Virol. 2017;60:156-164.

16. Pangty KS, Singh S, Goswami R, Saikumar G. Detection of BPV-1 and -2 and quantification of BPV-1 by real-time PCR in cutaneous warts in cattle and buffaloes. Transbound Emerg Dis. 2010;57:185196.

17. Mehmet T, Yakup Y, Mahmut S, Seval B, Volkan Y, Ali HK, Erhan G. A Histopathological, immunohistochemical and molecular study of cutaneous bovine papillomatosis. Kafkas Univ Vet Fak Derg. 2012;18(5):739-744.

18. Jelinek F, Tachezy R. Cutaneous papillomatosis in cattle. J Comp Pathol. 2005; 132:70-81.

19. Mohammed AH, Ahmed M, Shoni MO, Nahi YY. Molecular and phylogenetic analysis of bovine papillomavirus type 1: first report in Iraqi cattle. Advan in Virol. 2016;2143024:7.

20. Mohammed A, Hamad AS, Al-BannaA, Nahi YY. Treatment of bovine papilloma. Proceeding of the Eleventh Veterinary Scientific Conference; 2012 (b):25-32.

21. Ataseven VS, Kanat O, Ergun Y. Molecular identification of bovine papillomaviruses in dairy and beef cattle: First description of $\mathrm{Xi}$ and Epsilonpapillomavirus in Turkey, Turkish $\mathrm{J}$ Vet Anim Sci. 2016;40:757-763. 